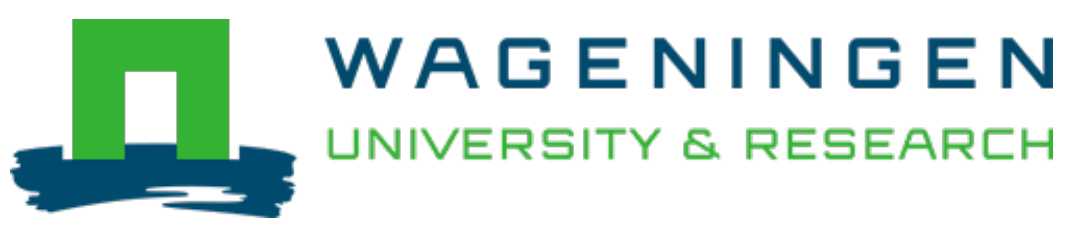

\title{
Bee abundance and soil nitrogen availability interactively modulate apple quality and quantity in intensive agricultural landscapes of China
}

\author{
Agriculture, Ecosystems and Environment \\ Wu, Panlong; Tscharntke, Teja; Westphal, Catrin; Wang, Meina; Olhnuud, Aruhan et al \\ https://doi.org/10.1016/j.agee.2020.107168
}

This publication is made publicly available in the institutional repository of Wageningen University and Research, under the terms of article $25 \mathrm{fa}$ of the Dutch Copyright Act, also known as the Amendment Taverne. This has been done with explicit consent by the author.

Article 25 fa states that the author of a short scientific work funded either wholly or partially by Dutch public funds is entitled to make that work publicly available for no consideration following a reasonable period of time after the work was first published, provided that clear reference is made to the source of the first publication of the work.

This publication is distributed under The Association of Universities in the Netherlands (VSNU) 'Article $25 \mathrm{fa}$ implementation' project. In this project research outputs of researchers employed by Dutch Universities that comply with the legal requirements of Article $25 \mathrm{fa}$ of the Dutch Copyright Act are distributed online and free of cost or other barriers in institutional repositories. Research outputs are distributed six months after their first online publication in the original published version and with proper attribution to the source of the original publication.

You are permitted to download and use the publication for personal purposes. All rights remain with the author(s) and / or copyright owner(s) of this work. Any use of the publication or parts of it other than authorised under article $25 \mathrm{fa}$ of the Dutch Copyright act is prohibited. Wageningen University \& Research and the author(s) of this publication shall not be held responsible or liable for any damages resulting from your (re)use of this publication.

For questions regarding the public availability of this publication please contact openscience.library@wur.nl 


\title{
Bee abundance and soil nitrogen availability interactively modulate apple quality and quantity in intensive agricultural landscapes of China
}

\author{
Panlong $\mathrm{Wu}^{\mathrm{a}}$, Teja Tscharntke ${ }^{\mathrm{b}}$, Catrin Westphal ${ }^{\mathrm{c}}$, Meina Wang ${ }^{\mathrm{a}}$, Aruhan Olhnuud ${ }^{\mathrm{a}}$, \\ Huanli Xu ${ }^{\mathrm{d}}$, Zhenrong $\mathrm{Yu}^{\mathrm{a}}$, Wopke van $\operatorname{der}$ Werf $^{\mathrm{e}}$, Yunhui Liu ${ }^{\mathrm{a}, *}$ \\ a Beijing Key Laboratory of Biodiversity and Organic Farming, College of Resources and Environmental Sciences, China Agricultural University, Beijing 100193, China \\ ${ }^{\mathrm{b}}$ Agroecology, Department of Crop Sciences, University of Göttingen, Göttingen 37077, Germany \\ ${ }^{\mathrm{c}}$ Functional Agrobiodiversity, Department of Crop Sciences, University of Göttingen, Göttingen 37077, Germany \\ ${ }^{\mathrm{d}}$ College of Plant Protection, China Agricultural University, Beijing 100193, China \\ ${ }^{\mathrm{e}}$ Centre for Crop Systems Analysis, Wageningen University, P.O. Box 430, 6700 AK Wageningen, the Netherlands
}

\section{A R T I C L E I N F O}

\section{Keywords:}

Pollinator

Landscape composition

Robinia forests

Ecological intensification

\begin{abstract}
A B S T R A C T
Bees provide important pollination services for crops, but pollination limitation is a common problem in agricultural landscapes worldwide. To promote ecological intensification in fruit production, more knowledge is needed concerning the interacting effects of insect pollination services and soil fertility on crop quality and quantity. We investigated the effects of three pollination treatments (open, self and hand pollination) on apple quantity and quality parameters. We also analyzed the effects of bee abundance (wild bees and managed honeybees (Apis mellifera)) and soil nitrogen on fruit quantity and quality, and the responses of bee abundance and species richness to landscape metrics. Apple fruit set and yield of open pollinated flowers increased by $57 \%$ and $25 \mathrm{t} /$ ha (compared to bagged controls), respectively. Hand pollination further enhanced yields by $7 \mathrm{t} / \mathrm{ha}$ (compared to open pollination; i.e. to $39 \mathrm{t} / \mathrm{ha}$ ), indicating pollination limitation in the orchards. Seed number was highest in open pollinated fruits, and increased with bee abundance if soil nitrogen was low, but decreased with bee abundance at high nitrogen levels, possibly due to higher flower density resulting in pollinator dilution effects. Higher seed numbers reduced the proportion of deformed apples and thus increased fruit quality. The percent of surrounding semi-natural habitats positively affected species richness of wild bees in apple orchards. We conclude that yield and quality of apples may benefit from ecological intensification comprising the augmentation of wild bees by semi-natural habitat and lowering of fertilizer inputs.
\end{abstract}

\section{Introduction}

Pollinators provide important crop pollination services (Klein et al., 2007). Growing evidence suggests that pollinators not only increase crop yield (e.g. Hoehn et al., 2008), but also improve quality traits, such as oil contents of oilseed rape (Bartomeus et al., 2014), shape, color, sugar-acid ratios and shelf life of strawberries (Klatt et al., 2014; Wietzke et al., 2018), sweetness of passion fruit (Junqueira and Augusto, 2017), and seed number and fruit size of apples (Sapir et al., 2017). Pollinators therefore create enormous economic value which has been estimated at \$235-577 billion globally in 2015 (Lautenbach et al., 2012).

However, pollination deficits have been detected worldwide due to declines of wild and managed pollinators (Potts et al., 2010). These changes are driven by multiple drivers, including climate change, and spread of pathogens and invasive species (Schweiger et al., 2010; Vanbergen and the Insect Pollinators Initiative, 2013), but the most important drivers are agricultural intensification and the loss and fragmentation of semi-natural habitats (Tscharntke et al., 2012). Interacting effects of multiple drivers can reinforce pollinator declines but such interactions are rarely studied (Tylianakis et al., 2008; González-Varo et al., 2013). With respect to more sustainable agricultural production, more knowledge is needed on potential cascading effects of soil nutrient levels on botanical traits of crops and how they affect pollinator communities and pollination services (David et al., 2019). Case studies on few crops show that pollination benefits may be maximized at intermediate or low nitrogen levels (Tamburini et al., 2017; Ramos et al., 2018), because nitrogen enrichment can increase flower abundance (apple, Hill-Cottingham, 1963; pumpkin, Hoover et al., 2012), and affect

\footnotetext{
* Corresponding author.

E-mail address: liuyh@cau.edu.cn (Y. Liu).
} 
the onset of flowering (pumpkin, Hoover et al., 2012), potentially altering flower visitor community composition or behavior (pumpkins, Hoover et al., 2012; common bean, Ramos et al., 2018) and even crop yield and quality (oilseed rape, Marini et al., 2015; sunflower, Tamburini et al., 2017). Ecological intensification is therefore proposed to improve pollinator diversity and associated pollination services through reduction of agrochemical inputs and the protection of semi-natural habitats in agricultural landscapes (Bommarco et al., 2013; Kleijn et al., 2019).

How to improve pollinators and associated pollination services in agricultural landscapes is increasingly studied in North America and Europe (Steward et al., 2014). Wild bees and honeybees represent two important groups of pollinators worldwide (Klein et al., 2007; Hein, 2009; Breeze et al., 2014), and they respond to different landscape and management variables (Rollin et al., 2013). For example, wild bees benefit from rich floral and nest resources in semi-natural habitats (Tscharntke et al., 2012), while abundance of honeybees is strongly related to managed beehives (Cunningham et al., 2016). However, our understanding of the links between wild and managed bees and landscape variables has remained very limited for China's smallholder-dominated landscapes (Steward et al., 2014; Zou et al., 2017).

Local management practices, such as flowering ground-cover (Blaauw and Isaacs, 2014), use of pesticides (Park et al., 2015), organic cropping (Holzschuh et al., 2008), and beehive management (Liu and Li, 2014), impact wild and managed bees and associated pollination services (Kennedy et al., 2013; Westphal et al., 2015). However, few studies have investigated effects of soil nutrients and their interactions with bees on pollination services (Burkle and Irwin, 2010), especially for China with nitrogen inputs now at the levels of diminishing returns for crop yield and increasing environmental pollution ( $\mathrm{Ju}$ et al., 2009; Zhang et al., 2015). In our study area, excessive nitrogen fertilizer is applied in apple orchards (Yang et al., 2017; Chen et al., 2018), and apple growers frequently control ground-cover weeds by mowing, plowing or herbicides. It is poorly understood how these local management practices alone and in interaction with landscape affect bee diversity and their influence on fruit yield and quality.

In this study, we are interested in quantifying the contribution of bees and local management to apple pollination, and determine how local and landscape variables influence bee diversity in intensive agricultural landscapes. Apple is the selected crop, because it is pollinatordependent and China harbors the world's largest apple planting area in the world (Chen et al., 2010). Previous research (Pardo and Borges, 2020) and our preliminary investigations have shown that bees (both managed honeybees, Apis mellifera, and wild bees) are the main visitors of apple flowers. We hypothesized that 1) pollination services by bees enhance yields and fruit quality of apples; 2) there is pollination deficiency for apples in intensive agricultural landscapes; 3) apple yield and quality are related to bee abundance and diversity, soil nutrients and their interactions; and 4) wild bee diversity positively responds to surrounding semi-natural habitats, whereas honeybee abundance decreases with distance to beehives.

\section{Materials and methods}

\subsection{Study area}

We conducted this study in Luochuan County (109 $13^{\prime} 14^{\prime \prime}$ $109^{\circ} 45^{\prime} 47^{\prime \prime} \mathrm{N}, 35^{\circ} 26^{\prime} 29^{\prime \prime}-36^{\circ} 04^{\prime} 12^{\prime \prime} \mathrm{E}$, altitude $650-1481 \mathrm{~m}$ ) in Shaanxi Province on the Loess Plateau, a location with sustainability challenges due to long-term soil erosion due to climate changes, population growth and deforestation (Zhao et al., 2013). The local climate is a warm temperate semi-humid continental monsoon climate, with an average annual rainfall of $\sim 662 \mathrm{~mm}$ and an average annual temperature of $\sim 9.2$ ${ }^{\circ} \mathrm{C}$. Since the 1970 s, as an important measure to alleviate soil erosion on the Loess Plateau, Robinia pseudoacacia has been artificially planted in ravines and abandoned fields in "Three North Shelterbelt Program" (1978-2050) and the "Grain for Green Project" (2000-2020). The resulting forests are characterized by little human disturbance and dominance of the flowering tree species $R$. pseudoacacia, and are the main semi-natural habitat in this region. To reduce soil erosion and increase economic income, apples are planted on the tableland (i.e. on the plateau) and have developed into one of the largest apple growing regions in China. Commercial beekeepers are attracted by the nectar and pollen resources of $R$. pseudoacacia and apple flowers to release honeybees during their blooming period.

\subsection{Bee sampling}

Fuji is the most common apple variety in the study area, and a total of 15 Fuji apple orchards (mean size $0.39 \pm 0.14$ (SD) ha) located along a landscape gradient were selected for this study (Fig. 1, Table A1). Pan traps were used to sample bees (Hymenoptera: Apoidea) continuously during the apple blooming period (20th to 29th April) in 2017. Three parallel transect lines of $40 \mathrm{~m}$ long and $10 \mathrm{~m}$ apart were established in each orchard, with a distance to the orchard edges of at least $15 \mathrm{~m}$. Metal stakes, each supporting one pan trap (yellow, white or blue, following Westphal et al., 2008, with $21 \mathrm{~cm}$ diameter and $10 \mathrm{~cm}$ depth) at a height of about $1.3 \mathrm{~m}$, were placed at $20 \mathrm{~m}$ intervals along each transect. Each pan trap was filled with about $400 \mathrm{ml}$ water and two drops of detergent per five liters of water. Traps were emptied and refilled every three days. We identified all bee specimens to species level (Wu, 1965 and 2000), and bee data from the nine traps per orchard were pooled for the entire sampling period.

\subsection{Three apple pollination treatments}

Three pollination treatments were set up to compare the contribution of pollinators to Fuji apple pollination, including open pollination allowing access to flowers by all pollinators, bagged controls preventing insects to visit flowers, and hand pollination using a small paint brush to pollinate apple flowers with a purchased pollen mixture of three other apple cultivars (Qinguan, Hongxing and Gala) for cross-pollination.

In each orchard, a total of 15 apple trees, distributed over three rows, were selected in the bee sampling area $(20 \mathrm{~m} \times 40 \mathrm{~m})$. On each tree, two branches and, on each, three inflorescences (average 5.2 flowers per inflorescence) were randomly chosen and marked to count the number of flower buds before bloom. Two inflorescences on each branch were covered with nylon mesh ( $1 \mathrm{~mm}$ width) bags, one as pollinator exclusion treatment, and the other as hand pollination treatment. The third inflorescence on each branch remained uncovered as open pollination treatment. Thus, in total, each pollination treatment was applied to thirty inflorescences per site. For hand pollination, one flower on each inflorescence was selected for supplementing pollen, and the remaining flowers (average 4.07 flowers) in the same inflorescence were removed because it was impossible to hand-pollinate all the flowers in an inflorescence due to the short and different flowering periods of flowers in the same inflorescence. All flowers on the other two inflorescences on each branch were retained until the fruit was formed to determine fruit set. After seven days, when the flowers were fading, bags were removed, and all small green fruits were counted to determine fruit set. At the same time, we thinned the fruit clusters of the self and open pollination treatments to ensure only one apple was kept per inflorescence if there were multiple apples on one inflorescence. These apples were labeled for later testing and subsequently managed conventionally by farmers, such as commercial bagging and pesticides application to prevent pest and pathogen. After apples were ripe in October 2017, we picked all marked apples before commercial harvest. To assess the quantity and quality of the produced apples, we determined for each apple in each treatment the fresh weight $(\mathrm{g})$, seed number, firmness $\left(\mathrm{kg} / \mathrm{cm}^{2}\right.$, using GY-1 penetrometer, Fengshen, China), sugar content (\%, using PAL-1 digital refractometer, Atago, Japan) and deformation (determined by visual 


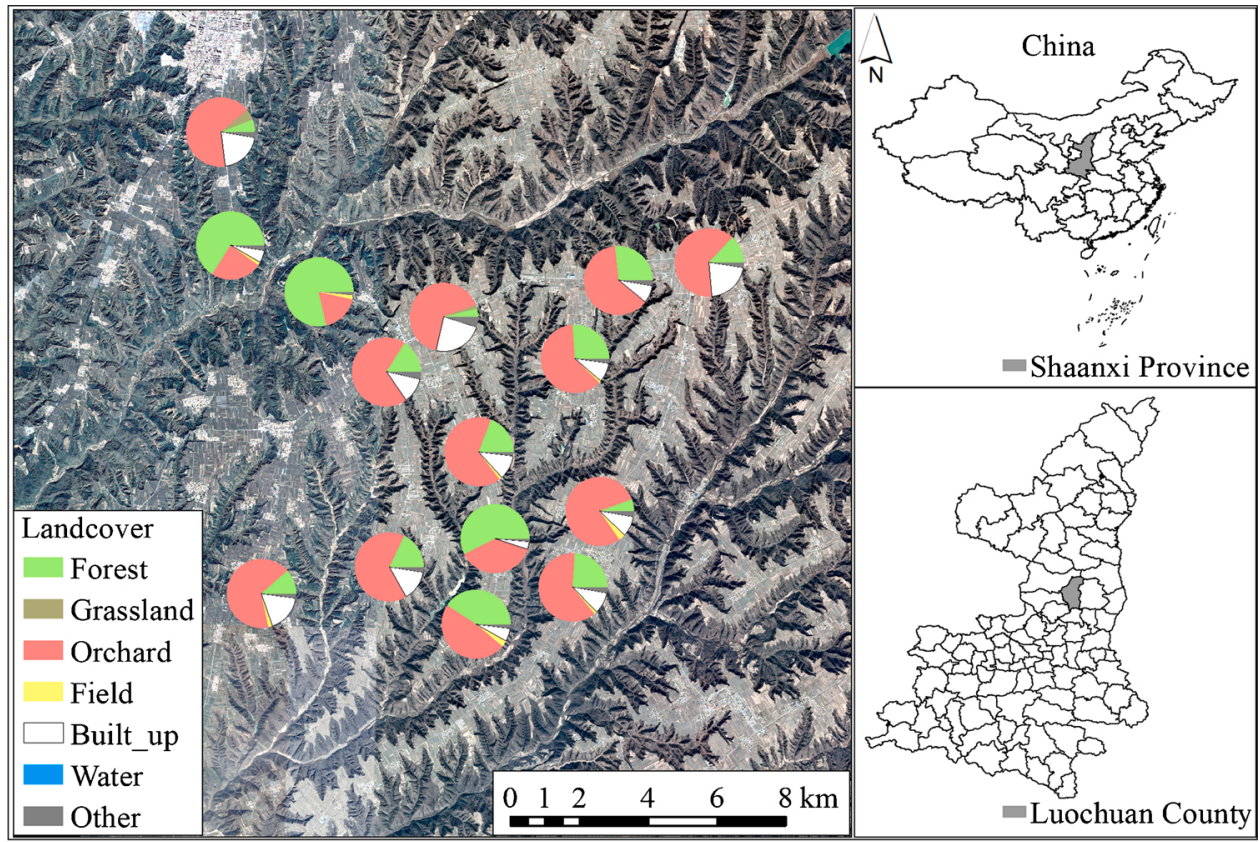

Fig. 1. The distribution of sampling sites in Luochuan County, Shaanxi Province, China.

inspection). We used $31.5 \mathrm{t} / \mathrm{ha}$ as mean yield of all orchards in the open pollination treatment based on the yield investigation in this region in 2017 by Xia et al. (2018). Following the method proposed by Garratt et al. (2014a), average yields of each orchard of different pollination treatments $(t)$ was estimated as:

$O_{i}=Y \times S_{i} \times W_{i}$

where $O_{i}$ represents the average apple yield per hectare of orchard $i$ under the open treatment. $Y$ represents the average yield per hectare of all orchards (31.5 t/ha) under open pollination, and $S_{i}$ and $W_{i}$ are the ratio of average final fruit set and fruit weight of orchard $i$ compared with average weight and final fruit set of all orchards in the open pollination treatment, respectively.

Final fruit set $S_{i}$ in each orchard in the open pollination treatment was calculated as

$S_{i}=F_{i} / N_{i}$

where $F_{i}$ and $N_{i}$ are the ratio of the average number of harvested fruits and the average number of flowers in each inflorescence of orchard $i$ compared with the average number of harvested fruits and the average number of flowers in each inflorescence of all orchard under open pollination treatment, respectively.

The yield of each orchard in treatment $t$ (bagged or hand-pollinated) was calculated as:

$Y_{t i}=O_{i} \times S_{t i} \times W_{t i}$

where $Y_{t i}$ represents average yield per hectare of orchard $i$ under treatment $t$ (bagged controls or hand pollination). $S_{t i}$ and $W_{t i}$ are the ratio of final fruit set and fruit weight in orchard $i$ in pollination treatment $t$ compared with average final fruit set and average weight of the corresponding orchard $i$ in the open pollination treatment, respectively.

Final fruit set $S_{t i}$ in orchard $i$ in treatment $t$ was calculated from the data using Eq. (2) with the data for the respective treatment substituted:

$S_{t i}=F_{t i} / N_{t i}$

where $F_{t i}$ and $N_{t i}$ are the ratio of the average number of harvested fruits and the average number of flowers in each inflorescence of orchard $i$ in pollination treatment $t$ compared with the average number of harvested fruits and the average number of flowers in each inflorescence of corresponding orchard $i$ under open pollination treatment, respectively.

\subsection{Local management survey}

All orchards were conventionally managed. Flowering ground-cover within the orchards was recognized as the main local management that may directly affect bees during the apple blooming period, considering farmers are not applying any pesticides or fungicides in this period to protect bee pollination for apples. We established five $1 \mathrm{~m} \times 1 \mathrm{~m}$ plots in the four corners and the center of the bee sampling area $(20 \mathrm{~m} \times 40 \mathrm{~m})$ covered by three transects. In each plot, we recorded flower proportion of each insect-pollinated herb species, and added them together to calculate the total flower coverage, subsequently averaged as the mean value for each site.

Apple farmers in the area commonly apply fertilizer three times a year, in March, June and November. Each apple tree receives the same amount of fertilizer, and the fertilization is applied near the base of each apple tree at a distance of approximately $40 \mathrm{~cm}$ from the trunk. Farmers mainly use urea as nitrogen fertilizer. Previous studies have shown that the average amount of nitrogen fertilizer used in apple orchards of this region is about $1200 \mathrm{~kg} \mathrm{~N} / \mathrm{ha}$, which far exceeds the recommended dosage of $240-360 \mathrm{~kg} \mathrm{~N} /$ ha (adjusted according to apple yield, Zhao et al., 2012; Yang et al., 2017). We randomly selected five apple trees in each orchard, and took one soil sample (5 $\mathrm{cm}$ diameter; $0-20 \mathrm{~cm}$ depth) near each selected apple tree at harvest in October 2017. The location of the soil sample was at the outer edge of the apple tree crown projected on the ground. The five random samples were mixed to measure soil total nitrogen (including both the organic and inorganic fraction, hereafter "soil nitrogen") using the Kjeldahl method (Gregorich and Carter, 2007) in each orchard.

\subsection{Landscape parameters}

Solitary bees dominated wild bee assemblages in our study, and their dispersal distance is usually less than $1 \mathrm{~km}$ (Steffan-Dewenter et al., 2002; Zurbuchen et al., 2010). We mapped land use surrounding the focal orchards at radius of $1 \mathrm{~km}$ in ArcGIS 10.2 (ESRI, 2014) based on Gaofen-2 satellite imagery (at $0.8 \mathrm{~m}$ resolution on 21th May 2016) and 
ground truthing in May 2017. Habitats were classified into seven categories, including 'Robinia forest', 'grassland', 'orchard', 'arable crop field', 'built-up area', 'water' and 'other' (Table A1). The first two habitat types were summed as semi-natural habitat in subsequent analysis to assess their aggregate effect on bees. 'Grassland' comprised both abandoned fields and natural grassland. Apples were the main crop in the study region, but there were also a few maize fields.

\subsection{Data analysis}

Firstly, we compared apple quantity and quality parameters among the three pollination treatments with generalized linear mixed-effects models (glmer function, R package "Ime4", Bates et al., 2015), using branches as a random variable nested within trees, within rows, and within sites. Response variables included fruit set, sugar content and deformation (Binomial distribution), fruit weight (Gamma distribution), firmness and yield (Gaussian distribution), and seed number (Poisson distribution). For continuous response variables, including fruit weight, firmness and yield, we fitted both Gamma and Gaussian distribution using the maximum likelihood estimation with the function fitdist in the R package "fitdistrplus" (Delignette-Muller and Dutang, 2014), and then chose the error distribution of each response variable based on the goodness-of-fit plots. The distributions of other response variables were chosen based on their data types (Zuur et al., 2009). Distribution assumptions were verified by evaluation of the residuals following response model estimation, using protocols of Zuur et al. (2009).

Secondly, we determined if soil nitrogen affected the response of apple quantity and quality parameters to pollination treatments (open, bagged and hand-pollinated) at the site level. All response variables or the log transformation followed the normal distribution, and we used linear models (lm function, R package "stats", R Core Team, 2018). For open pollination, total bee abundance or species richness (wild bees and managed honeybees (A. mellifera)), and its two-way interaction with soil nitrogen were also added into the full linear model as explanatory variables. Effects of seed number on apple pollination indices of the open pollination treatment were analyzed using linear models ( $\mathrm{lm}$ function, $\mathrm{R}$ package "stats", R Core Team, 2018).

Thirdly, to assess the optimal spatial scale where wild bees responded to percent of semi-natural habitat, we select three radii, 200, 500 and $1000 \mathrm{~m}$ using the "Connecting Analysis" tools to construct landscape models in ModelBuilder in ArcGIS 10.2 (ESRI, 2014). The spatial scale of $500 \mathrm{~m}$ was selected as the optimal scale for each response variable in the following analysis, based on the smallest value of AICc (corrected Akaike Information Criterion) obtained at this scale (Table A2). Distance from the center of each site to the nearest honeybee hive was calculated using the "Near Tool" of "Analysis Tools" in ArcGIS 10.2. Percent of semi-natural habitat was correlated with soil nitrogen (according to spearman rank correlation test, $\mathrm{p}$-values $=0.01, \mathrm{r}=-0.64$, see Table A3), we therefore constructed different generalized linear models to analyze their effects on abundance or species richness of wild bees. Percent of semi-natural habitat or soil nitrogen, flowering ground-cover and their interaction were included as explanatory variables in full models, with abundance or species richness of wild bees as the response variable. In case of overdispersion, generalized linear models with a negative binomial distribution (glm.nb, R package "MASS", Ripley et al., 2018) were used. We also used glm.nb models to analyze the response of honeybee abundance to the distance to honeybee hives, soil nitrogen, flowering ground-cover and their interaction.

In the second and the third analyses, the dredge function (R package "MuMIn", Barton, 2018) was used to select the best fitting models for each response variable based on AICc (Burnham and Anderson, 2002). The results showed that the optimal models were the null model only with the intercept and/or one single model with other explanatory variables for each response variable (Table A2, Table A5) based on $\Delta$ AICc $<2$. Spatial autocorrelation of the final model residuals was tested for each response variable using the "ncf" package (Bjornstad,
2019), and no significant spatial autocorrelation was detected in any case. The models were furthermore validated based on visual inspection of the plotted residuals versus the predicted values (Zuur et al., 2009). All analyses were performed using R (version 3.5.1, R Core Team, 2018).

\section{Results}

\subsection{Three apple pollination treatments}

In total, there were 5099 flowers and 787 ripe apples measured for fruit set and apple quantity and quality parameters, respectively. Pollination treatments significantly influenced apple quantity and quality parameters (Fig. 2, Table A4). Hand pollination showed the highest fruit set $(89.5 \pm 1.5 \%)$ and yield $(39.0 \pm 1.8 \mathrm{t} / \mathrm{ha})$, followed by open pollination (fruit set $63.8 \pm 1.3 \%$, yield $31.7 \pm 1.7 \mathrm{t} / \mathrm{ha}$ ), and finally by bagged controls (fruit set $7.2 \pm 0.6 \%$, yield $7.5 \pm 1.0 \mathrm{t} / \mathrm{ha}$ ). Bagged controls had lower fresh weight of individual apples $(183.1 \pm 4.6 \mathrm{~g})$ than the open $(202.3 \pm 2.8 \mathrm{~g})$ and hand pollinated treatments $(201.6 \pm 2.7 \mathrm{~g})$, while there was no significant difference between the latter. Open pollination increased seed number per apple $(5.4 \pm 0.2)$ compared to bagged controls $(3.2 \pm 0.4)$ and hand pollination $(3.4 \pm 0.1)$. Hand pollination showed the lowest proportion of deformed fruit $(24.2 \pm 2.3$ $\%$ of the apples), followed by open pollination (31.3 $\pm 2.5 \%$ ), and finally by bagged controls (42.7 $\pm 5.3 \%$ ). Bagged controls had higher firmness $\left(8.8 \pm 0.5 \mathrm{~kg} / \mathrm{cm}^{2}\right)$ than the open $\left(7.7 \pm 0.2 \mathrm{~kg} / \mathrm{cm}^{2}\right)$ and hand pollination treatments $\left(7.6 \pm 0.2 \mathrm{~kg} / \mathrm{cm}^{2}\right)$, while there was no significant difference between the latter. Sugar content was not significantly different among the three pollination treatments (hand pollination 12.6 $\pm 0.1 \%$, bagged $12.5 \pm 0.1 \%$, open $12.8 \pm 0.1 \%$ ).

\subsection{Effects of bee abundance, soil nitrogen and their interaction on apple pollination}

In total, we collected 1619 wild bees representing 42 species and 4783 honeybees (A. mellifera) using pan traps. The most abundant species of wild bees was Lasioglossum tessaranotatum, accounting for $33.0 \%$ of all wild bee individuals caught, followed by Eucera chinensis (25.5 \%).

Bee abundance effects on pollination in the open pollination treatment interacted with the effect of soil nitrogen. At low levels of soil nitrogen ( $<1.5 \mathrm{~g} / \mathrm{kg}$ ), we found a positive effect of bee abundance on seed numbers whereas seed numbers declined with bee abundance at high levels of nitrogen ( $>1.5 \mathrm{~g} / \mathrm{kg}$, Fig. 3a, Table 1). Furthermore, with increasing seed numbers the proportion of deformed apples diminished (Fig. 4a, Table A6). Soil nitrogen positively affected sugar content in both the open (Fig. 3b, Table 1) and hand pollination treatment (Fig. 4b, Table A7). Other apple quality parameters, including apple weight, fruit set, yield and firmness, were not affected by bees or soil nitrogen (Tables A5 and A7).

\subsection{Responses of bees to local and landscape variables}

The percent of semi-natural habitats in the landscape had a positive effect on the species richness of wild bees (Fig. 5a, Table 2), but not on wild bee abundance (Table A2). Honeybee abundance decreased with increasing distance to beehives (Fig. 5b, Table 2).

\section{Discussion}

In this study, we found that bee abundance significantly improved apple pollination and yield in the open pollination treatment. The positive effect of bees on seed number was greatest at low soil nitrogen content and reduced fruit deformation. The two important pollinator groups of apples, wild bees and honeybees, benefited from high amounts of semi-natural habitats in the surrounding landscape and nearby beehives, respectively.

Apples are self-incompatible and need pollinators to transfer pollen, 

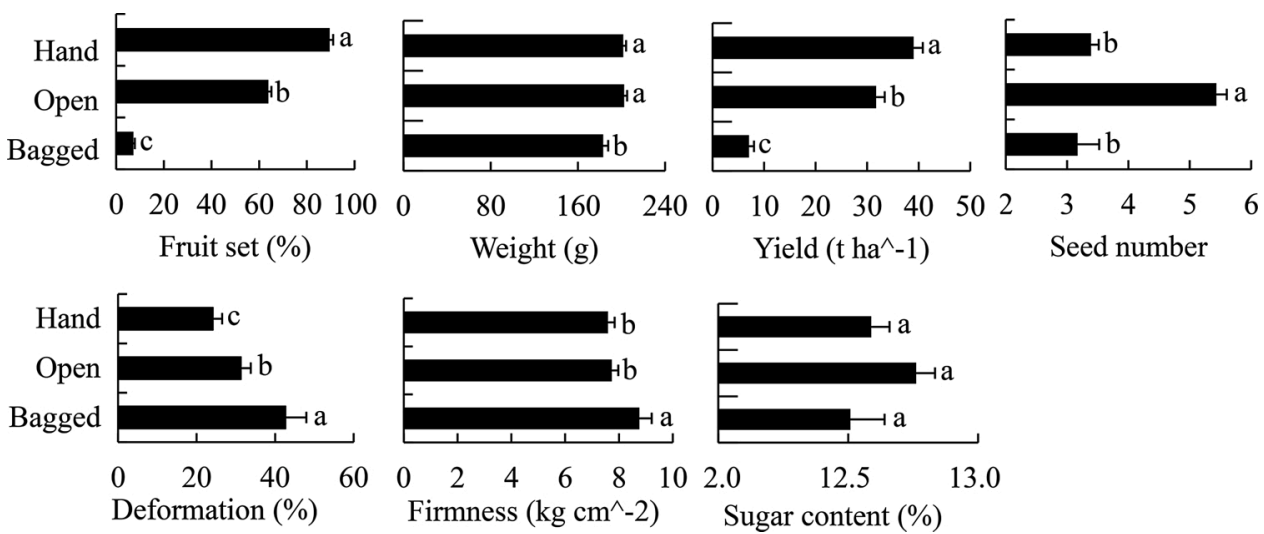

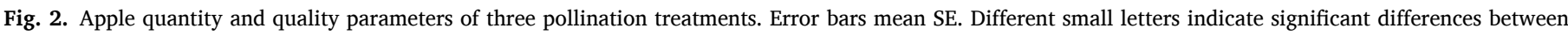
treatments $(\mathrm{p}<0.05)$.
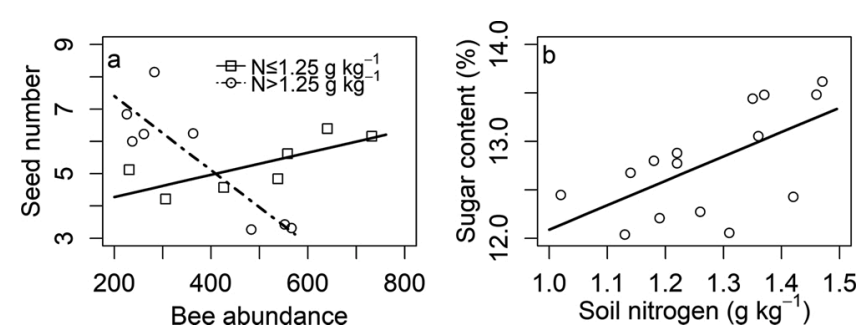

Fig. 3. Effects of bee abundance, soil nitrogen $(\mathrm{N})$ and their interaction on seed number (a) and sugar content (b) in open pollination. To illustrate the interaction between soil nitrogen and bee abundance we split the data set and grouped the sites with soil nitrogen $(\mathrm{N})$ values above and below the median for the plot. Note: in the model soil content is a continuous variable.

Table 1

Results from simple linear models ( $\mathrm{lm}$ ) on the effects of bees, soil nutrient and their interaction on a) seed number and b) sugar content in open pollination treatment.

\begin{tabular}{|c|c|c|c|c|}
\hline & Estimate & Std.Error & $\mathrm{z}$ value & $\operatorname{Pr}(>|z|)$ \\
\hline \multicolumn{5}{|l|}{ a) Seed number } \\
\hline (Intercept) & -25.22 & 8.81 & -2.86 & 0.015 \\
\hline Bee abundance & 0.066 & 0.017 & 4.01 & 0.002 \\
\hline Soil nitrogen & 25.14 & 6.84 & 3.68 & 0.004 \\
\hline Bee abundance: soil nitrogen & -0.056 & 0.013 & -4.24 & 0.001 \\
\hline \multicolumn{5}{|l|}{ b) Sugar content } \\
\hline (Intercept) & 9.57 & 1.15 & 8.29 & $<0.001$ \\
\hline Soil nitrogen & 2.52 & 0.90 & 2.79 & 0.015 \\
\hline
\end{tabular}
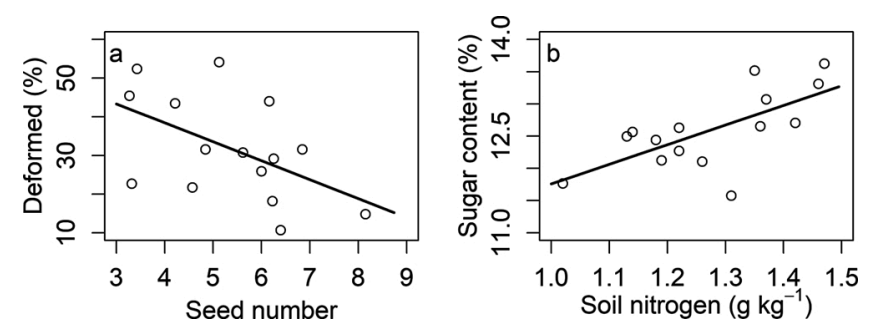

Fig. 4. The effect of seed number on the proportion of deformed apples in open pollination (a) and the effect of soil nitrogen on sugar content in hand pollination (b).

typically from trees of another apple variety, for fertilization (Ramírez et al., 2013). In accordance with our first hypothesis, apple quantity and quality were higher in open pollination than with pollinator exclusion. However, higher fruit set $(25.7 \%)$ and yield $(7.3 \mathrm{t} / \mathrm{ha})$ with hand pollination in comparison to open pollination highlighted that there was still pollination deficiency in this study area, possibly due to insufficient pollinators. A pollination deficit of apples was also reported in UK (Garratt, et al., 2014a), USA (Blitzer et al., 2016) and other regions in China (Wang et al., 2018), which suggests that the deficiency of pollinators in the apple system may be a global phenomenon, and highlights the importance to enhance pollinator populations in agricultural landscapes.

Hand pollination is an important local measure to reduce fruit pollination deficits in some regions of China where pollinators are severely missing (Liu and Li, 2014). Our results indicated that hand pollination is still an option to decrease apple deformation and increase apple fruit set and yield, although seed numbers were higher under open pollination in our study. Higher seed number with open pollination than with hand pollination may be due to pollen quality, which may well differ between insect deposited pollen and the commercial pollen used for hand pollination. Negative effects of hand pollination on apple seed number were also reported by Visser and Verhaegh (1980), but the physiological basis is not clear. Firmness was lower with hand and open pollination than in bagged controls, possibly because apples with low level of pollination matured later than those with higher level of pollination, and firmness generally declines during fruit maturation (Volz et al., 2003; Garratt et al., 2014b). Sugar content may be mainly related to other factors, such as soil nutrients in our study, thus it did not vary among different pollination treatments (Garratt et al., 2014a). Bee pollination may be better for farmers' profit in regions where labor is seriously scarce and expensive, because hand pollination costs 50 times more than releasing honeybees (565.8 RMB/t vs $11.3 \mathrm{RMB} / \mathrm{t}$ ) in China (Liu and Li, 2014).

In this study, we did not detect an effect of soil nitrogen on apple yield, possibly because of the excessive nitrogen amounts applied by farmers in this area (farmers apply $\sim 1200 \mathrm{~kg} \mathrm{~N} / \mathrm{ha}$ versus a recommended dose of 240-360 kg N/ha, Zhao et al., 2012; Yang et al., 2017). Excessive soil nitrogen may not significantly improve crop yield due to the limited demand of crop growth but it will increase agricultural production costs and spillover to the environment (Ju et al., 2009). We found that soil nitrogen interacted with the effect of bees on apple seed numbers related to deformation, possibly because high soil nitrogen decreased bee visitation rate by increasing the flower number. Increased flower numbers in response to high nitrogen levels have already been observed for apples (Hill-Cottingham, 1963) and pumpkins (Hoover et al., 2012). Higher numbers of flowers may decrease the flower visitation rates and consequently the seed numbers per individual fruit. This will be especially true at times of synchronous crop flowering, due to the dilution of the bee populations (Veddeler et al., 2006) and subsequent decrease of seed number in focal plants (Holzschuh et al., 2011). Previous studies have shown that soil nitrogen can affect pollinator 

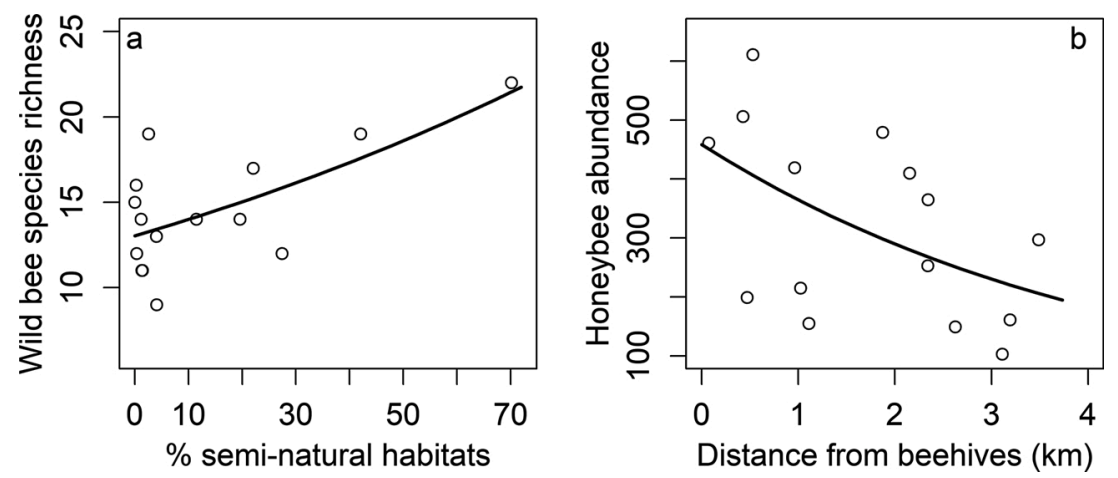

Fig. 5. Responses of species richness of wild bees (a) and honeybee abundance (b) to landscape variables.

\section{Table 2}

Results from generalized linear models (or with a negative binomial distribution) on the effects of landscape variables, soil nitrogen, flowering ground-cover and their interaction on a) species richness of wild bees ( $\mathrm{glm}$ ) and b) honeybee abundance (glm.nb). Model coefficients are not presented for wile bee abundance, because the best fitting model only included the intercept.

\begin{tabular}{lllll}
\hline & Estimate & Std.Error & $\mathrm{z}$ value & $\operatorname{Pr}(>|\mathrm{z}|)$ \\
\hline $\begin{array}{l}\text { a) Wild bee richness } \\
\text { (Intercept) }\end{array}$ & 2.57 & 0.086 & 29.94 & $<0.001$ \\
$\begin{array}{l}\text { Percent of semi-natural habitats } \\
\text { b) Honeybee abundance }\end{array}$ & 0.0071 & 0.0031 & 2.28 & 0.023 \\
$\begin{array}{l}\text { (Intercept) } \\
\text { Distance to beehive }\end{array}$ & 6.13 & 0.21 & 29.39 & $<0.001$ \\
& -0.23 & 0.10 & -2.23 & 0.026 \\
\hline
\end{tabular}

visitation by changing the characteristics of flowers. For example, high nitrogen accelerates the onset of flowering (pumpkins, Hoover et al., 2012), and changes nectar chemistry (Agrostemma githago, Gardener and Gillman, 2001; pumpkins, Hoover et al., 2012), and affects the species composition and behavior of pollinators (common beans, Ramos et al., 2018). Hence, pollination benefits may be maximized at the low or intermediate nitrogen level (Tamburini et al., 2017; Ramos et al., 2018). However, other studies found opposite effects of soil nitrogen on non-crop plant species. For example, nitrogen addition delayed the onset of flowering (Heteropappus altaicus, Xia and Wan, 2013; Anemone trullifolia and Caltha scapose, Liu et al., 2017). In Potentilla, nitrogen addition decreased flower production, and there were no effects of nitrogen addition on the pollinator visitation rates to Potentilla flowers at the flower level (Burkle and Irwin, 2010). Interspecies differences and soil nitrogen levels may be the possible reasons for contrasting responses of different plant species to soil nitrogen. Future research should therefore confirm the role of different soil nitrogen levels in altering plant-pollinator interactions based on a wide range of plant species to efficiently manage soil nutrients and pollination services (David et al., 2019).

The exclusion treatment showed that pollinators contributed substantially to apple yield, but the regression analysis across sites did not find a relationship between bee abundance or species richness and apple yield in the open pollination treatment. One possible reason is the limitations of the pollinator sampling method. While there is no doubt that pan traps do give information on pollinator abundance and diversity, direct observations on bee visitation are the most direct method to investigate the true pollinator species. The choice of method needs to consider sample coverage, collector bias and the short flowering period of crops and find a suitable compromise between demands and possibilities (Westphal et al., 2008; Nielsen et al., 2011). Future studies therefore need to compare the effectiveness of these two methods in investigating true apple pollinators.

A reason why bee diversity did not affect apple pollination in this study, could be that few dominant bee species provided most of the pollination services, e.g. A. mellifera, L. tessaranotatum and E. chinensis in our study area, while rare species contribute more to species diversity than to service provision (Kleijn et al., 2015; Winfree et al., 2015). Nevertheless, high bee diversity may provide temporal and spatial complementarity of services, and thus compensate for the negative effects of environmental changes, such as large field size, excessive fertilizer, pesticides and climate changes, thus supporting more reliable and stable pollination services (Garibaldi et al., 2016; Fijen et al., 2018).

As two important pollinator groups, wild bees and honeybees, both contribute to apple pollination, increasing total bee abundance is important to reduce fruit pollination deficits (Martins et al., 2015). Honeybees have been proven to be capable of providing pollination services to apples, although their pollination efficiency per individual is generally lower than that of wild bees (Garratt et al., 2016). The Chinese government recommends famers use managed honeybees to pollinate fruit crops, and it has established 20 demonstration sites $\left(5419 \mathrm{hm}^{2}\right)$ in 14 provinces since 2014 to demonstrate the role of honeybees in crop pollination to farmers (Zhao et al., 2015), such as releasing A. mellifera in apple orchards (Liu and Li, 2014). So far, there are not many farmers that rent or raise honeybees in the study area, due to lack of knowledge of honeybee management and pollination (Liu and Li, 2014). Beekeepers in the study region prefer that honeybees collect honey of $R$. pseudoacacia, rather than that of fruit crops, thus the beehives are often placed near the semi-natural habitat. These practices result in a mismatch between the demand and supply of honeybees. A mutually beneficial relationship therefore should be established among different stakeholders in crop pollination to decrease the distance between beehives and orchards for fruit pollination (Kleinman and Suryanarayanan, 2019).

Compared to honeybees, previous studies suggested that wild bees may be more efficient pollinators than honeybees for apples (Garratt et al., 2016) and other pollinator-dependent crops (Garibaldi et al., 2013), due to their temporal and spatial complementarity in pollination, such as various foraging periods and locations, different preferences for plant varieties or species (Hoehn et al., 2008; Brittain et al., 2013) and high tolerance under changing weather conditions (Vicens and Bosch, 2000). The low efficiency of honeybees in apple pollination (Garratt et al., 2016) and their dominance may be one of the main reasons for apple pollination limitation (Martins et al., 2015). However, China lacks policies to protect wild pollinators in agricultural landscapes, although protecting wild bees in agricultural landscapes may be more important than considering only honeybees.

Our results indicate that wild bee diversity in orchards was positively affected by semi-natural habitats, such as Robinia forests, the main seminatural habitat type in this area. Diverse flowering species and little human disturbance made this habitat rich in floral and nest resources for pollinators. This supports findings that reforestation can positively affect biodiversity if associated with diverse natural plants and little human disturbance (Zou et al., 2015). In contrast, plantation forests in other regions of China showed negative effects on wild bees in surrounding apple orchards if anemochorous tree species and intensive 
habitat management were used (Wu et al., 2019). For high pollinator resources and associated pollination services in agricultural landscapes, future restoration of semi-natural habitats should therefore consider diverse flowering tree species and pollinator-friendly management.

We did not detect any effect of flowering ground-cover within orchards on bees in the orchard, possibly due to the highly intensive management within orchards. In our study area, farmers frequently controlled weed growth to prevent competition with apple trees for nutrients and water by mowing, plowing and herbicide application, which resulted in orchards lacking rich wild floral (only $4.3 \%$ flower cover by weeds) and nesting resources for bees. However, previous studies showed a positive effect of flowering ground-cover on honeybees (Földesi et al., 2016) and wild bees (Campbell et al., 2017; Wu et al., 2019) in apple orchards. The flowering ground-cover in our orchards appeared to be too low to be influential. Pollinator-friendly management therefore should be used in both local orchards and surrounding seminatural habitats for more diverse pollinator diversity in orchards and whole agricultural landscapes (Kennedy et al., 2013; Westphal et al., 2015).

\section{Conclusions}

Our findings demonstrate the importance of pollination services to produce high quantity and good quality of apple fruits in Chinese orchards which were shown to suffer from considerable pollination limitation. Fruits in open pollinated flowers had higher seed numbers, leading to higher quality fruits with a lower rate of deformation than self-pollinated flowers, whereas the positive relationship between bee abundance and seed numbers was counteracted by high soil nitrogen. These observations highlight the potential of ecological intensification (Bommarco et al., 2013), with reduced external inputs of fertilizer and enhanced pollination services, resulting in a more environmentally friendly management approach in apple production. Pollination services can be promoted through the restoration of semi-natural habitats, in case of pollination limitation due to wild bee declines, and managed honeybees could be introduced to the orchards to further supplement natural pollination services by wild bees.

\section{Declaration of Competing Interest}

The authors report no declarations of interest.

\section{Acknowledgements}

We are grateful to Bohui Xia and Chen Chen for their help in field work, and to Marjolein Lof at Wageningen University \& Research and Felipe Libran at the University of Göttingen for their kind assistance with the data analysis. We thank Jiaxing Huang in Institute of Apicultural Research for his suggestions on the experimental design and the manuscript. We thank the owners of the orchards for their cooperation with our work, and the National Natural Science Foundation of China (NO. 41871186), the National Key R\&D Program of China (NO. 2018YFC0507204), the Natural Science Foundation of Beijing Municipality (NO. 5162017), and the Chinese Universities Scientific Fund (NO. 2019TC131). CW is grateful for funding by the Deutsche Forschungsgemeinschaft (DFG, German Research Foundation)- project number 405945293.

\section{Appendix A. Supplementary data}

Supplementary material related to this article can be found, in the online version, at doi:https://doi.org/10.1016/j.agee.2020.107168.

\section{References}

Bartomeus, I., Potts, S.G., Steffan-Dewenter, I., Vaissière, B.E., Woyciechowski, M., Krewenka, K.M., Tscheulin, T., Roberts, S.P.M., Szentgyörgyi, H., Westphal, C., Bommarco, R., 2014. Contribution of insect pollinators to crop yield and quality varies with agricultural intensification. PeerJ 2, e328.

Barton, K., 2018. MuMIn: Multi-Model Inference. R package version 1.42.1.

Bates, D., Mächler, M., Bolker, B.M., Walker, S.C., 2015. Fitting linear mixed-effects models using lme4. J. Stat. Software 67 (1), 1-48.

Bjornstad, O.N., 2019. Package 'ncf'. Spatial Covariance Functions.

Blaauw, B.R., Isaacs, R., 2014. Flower plantings increase wild bee abundance and the pollination services provided to a pollination-dependent crop. J. Appl. Ecol. 51, 890-898.

Blitzer, E.J., Gibbs, J., Park, M.G., Danforth, B.N., 2016. Pollination services for apple are dependent on diverse wild bee communities. Agric. Ecosyst. Environ. 221, 1-7.

Bommarco, R., Kleijn, D., Potts, S.G., 2013. Ecological intensification: harnessing ecosystem services for food security. Trends Ecol. Evol. 28, 230-238.

Breeze, T.D., Vaissière, B.E., Bommarco, R., Petanidou, T., Seraphides, N., Kozák, L., Scheper, J., Biesmeijer, J.C., Kleijn, D., Gyldenkærne, S., Moretti, M., Holzschuh, A., Steffan-Dewenter, I., Stout, J.C., Pärtel, M., Zobel, M., Potts, S.G., 2014. Agricultural policies exacerbate honeybee pollination service supply-demand mismatches across Europe. PLoS One 9, e82996.

Brittain, C., Kremen, C., Klein, A.M., 2013. Biodiversity buffers pollination from changes in environmental conditions. Glob. Change Biol. Bioenergy 19, 540-547.

Burkle, L.A., Irwin, R.E., 2010. Beyond biomass: measuring the effects of communitylevel nitrogen enrichment on floral traits, pollinator visitation and plant reproduction. J. Ecol. 98, 705-717.

Burnham, K.P., Anderson, D.R., 2002. Model Selection and Multimodel Inference, 2nd. edn. Springer-Verlag, New York.

Campbell, A.J., Wilby, A., Sutton, P., Wäckers, F.L., 2017. Do sown flower strips boost wild pollinator abundance and pollination services in a spring-flowering crop? A case study from UK cider apple orchards. Agric. Ecosyst. Environ. 239, 20-29.

Chen, X.S., Han, M.Y., Su, G.L., Liu, F.Z., Guo, G.N., Jiang, Y.M., Mao, Z.Q., Peng, F.T., Shu, H.R., 2010. Discussion on today's world apple industry trends and the suggestions on sustainable and efficient development of apple industry in China. J. Fruit Sci. 27, 598-604.

Chen, C.X., Liu, Z.J., Chen, Z.J., Huo, B.Q., Zhou, J.B., 2018. Evaluating the situation of fertilization and soil fertility in new and old apple orchards of the Loess Plateau. Chin. J. Soil Sci. 49, 1144-1149 (in Chinese).

Cunningham, S.A., Fournier, A., Neave, M.J., Le Feuvre, D., 2016. Improving spatial arrangement of honeybee colonies to avoid pollination shortfall and depressed fruit set. J. Appl. Ecol. 53, 350-359.

David, T.I., Storkey, J., Stevens, C.J., 2019. Understanding how changing soil nitrogen affects plant-pollinator interactions. Arthropod. Interact. 13, 671-684.

Delignette-Muller, M.L., Dutang, C., 2014. Fitdistrplus: an r package for fitting distributions. J. Stat. Software 64, 1-34.

ESRI, 2014. ArcGIS 10.2 for Desktop. ESRI, Redlands, CA.

Fijen, T.P., Scheper, J.A., Boom, T.M., Janssen, N., Raemakers, I., Kleijn, D., 2018. Insect pollination is at least as important for marketable crop yield as plant quality in a seed crop. Ecol. Lett. 21, 1704-1713.

Földesi, R., Kovács-Hostyánszki, A., Körösi, Á., Somay, L., Elek, Z., Markó, V., Sárospataki, M., Bakos, R., Varga, A., Nyisztor, K., Báldi, A., 2016. Relationships between wild bees, hoverflies and pollination success in apple orchards with different landscape contexts. Agric. For. Entomol. 18, 68-75.

Gardener, M.C., Gillman, M.P., 2001. The effects of soil fertilizer on amino acids in the floral nectar of corncockle, Agrostemma githago (Caryophyllaceae). Oikos 92, $101-106$.

Garibaldi, L.A., Steffan-Dewenter, I., Winfree, R., Aizen, M.A., Bommarco, R., Cunningham, S.A., Kremen, C., Carvalheiro, L.G., Harder, L.D., Afik, O., Bartomeus, I., Benjamin, F., Boreux, V., Cariveau, D., Chacoff, N.P., Dudenhöffer, J. H., Freitas, B.M., Ghazoul, J., Greenleaf, S., Hipolito, J., Holzschuh, A., Howlett, B., Isaacs, R., Javorek, S.K., Kennedy, C.M., Krewenka, K.M., Krishnan, S., Mandelik, Y., Mayfield, M.M., Motzke, I., Munyuli, T., Nault, B.A., Otieno, M., Petersen, J., Pisanty, G., Potts, S.G., Rader, R., Ricketts, T.H., Rundlöf, M., Seymour, C.L., Schuepp, C., Szentgyorgyi, H., Taki, H., Tscharntke, T., Vergara, C.H., Viana, B.F., Wanger, T.C., Westphal, C., Williams, N., Klein, A.M., 2013. Wild pollinators enhance fruit set of crops regardless of honey bee abundance. Science 339, 1608-1611.

Garibaldi, L.A., Carvalheiro, L.G., Vaissiere, B.E., Gemmill-Herren, B., Hipolito, J., Freitas, B.M., Ngo, H.T., Azzu, N., Saez, A., Astrom, J., An, J., Blochtein, B., Buchori, D., Garcia, F.J.C., Oliveira da Silva, F., Devkota, K., Ribeiro, Md.F., Freitas, L., Gaglianone, M.C., Goss, M., Irshad, M., Kasina, M., Filho, A.J.S.P., Kiill, L. H.P., Kwapong, P., Parra, G.N., Pires, C., Pires, V., Rawal, R.S., Rizali, A., Saraiva, A. M., Veldtman, R., Viana, B.F., Witter, S., Zhang, H., 2016. Mutually beneficial pollinator diversity and crop yield outcomes in small and large farms. Science 351, 388-391.

Garratt, M.P.D., Breeze, T.D., Jenner, N., Polce, C., Biesmeijer, J.C., Potts, S.G., 2014a. Avoiding a bad apple: insect pollination enhances fruit quality and economic value. Agric. Ecosyst. Environ. 184, 34-40.

Garratt, M.P.D., Truslove, C.L., Coston, D.J., Evans, R.L., Moss, E.D., Dodson, C., Jenner, N., Biesmeijer, J.C., Potts, S.G., 2014b. Pollination deficits in UK apple orchards. J. Pollin. Ecol. 12, 9-14.

Garratt, M.P.D., Breeze, T.D., Boreux, V., Fountain, M.T., Mckerchar, M., Webber, S.M., Coston, D.J., Jenner, N., Dean, R., Westbury, D.B., Biesmeijer, J.C., Potts, S.G., 2016. Apple pollination: demand depends on variety and supply depends on pollinator identity. PLoS One 11, e0153889. 
González-Varo, J.P., Biesmeijer, J.C., Bommarco, R., Potts, S.G., Schweiger, O., Smith, H. G., Steffan-Dewenter, I., Szentgyörgyi, H., Woyciechowski, M., Vilà, M., 2013. Combined effects of global change pressures on animal-mediated pollination. Trends Ecol. Evol. 28, 524-530.

Gregorich, E.G., Carter, M.R., 2007. Soil Sampling and Methods of Analysis. CRC Press, Boca Raton, FL, USA.

Hein, L., 2009. The economic value of the pollination service, a review across scales. Open Ecol. J. 2, 74-82.

Hill-Cottingham, D.G., 1963. Effect of the time of application of fertilizer nitrogen on the growth, flowering and fruiting of maiden apple trees grown in sand culture. J. Hortic. Sci. 38, 242-251.

Hoehn, P., Tscharntke, T., Tylianakis, J.M., Steffan-Dewenter, I., 2008. Functional group diversity of bee pollinators increases crop yield. Proc. R. Soc. B 275, 2283-2291.

Holzschuh, A., Steffan-Dewenter, I., Tscharntke, T., 2008. Agricultural landscapes with organic crops support higher pollinator diversity. Oikos 117, 354-361.

Holzschuh, A., Dormann, C.F., Tscharntke, T., Steffan-Dewenter, I., 2011. Expansion of mass-flowering crops leads to transient pollinator dilution and reduced wild plant pollination. Proc. R. Soc. B 278, 3444-3451.

Hoover, S.E., Ladley, J.J., Shchepetkina, A.A., Tisch, M., Gieseg, S.P., Tylianakis, J.M., 2012. Warming, $\mathrm{CO}_{2}$, and nitrogen deposition interactively affect a plant-pollinator mutualism. Ecol. Lett. 15, 227-234.

Ju, X.T., Xing, G.X., Chen, X.P., Zhang, S.L., Zhang, L.J., Liu, X.J., Cui, Z.L., Yin, B., Christie, P., Zhu, Z.L., Zhang, F.S., 2009. Reducing environmental risk by improving N management in intensive Chinese agricultural systems. PNAS 106, 3041-3046.

Junqueira, C.N., Augusto, S.C., 2017. Bigger and sweeter passion fruits: effect of pollinator enhancement on fruit production and quality. Apidologie 48, 131-140.

Kennedy, C.M., Lonsdorf, E., Neel, M.C., Williams, N.M., Ricketts, T.H., Winfree, R., Bommarco, R., Brittain, C., Burley, A.L., Cariveau, D., Carvalheiro, L.G., Chacoff, N. P., Cunningham, S.A., Danforth, B.N., Dudenhoeffer, J., Elle, E., Gaines, H.R., Garibaldi, L.A., Gratton, C., Holzschuh, A., Isaacs, R., Javorek, S.K., Jha, S., Klein, A. M., Krewenka, K., Mandelik, Y., Mayfield, M.M., Morandin, L., Neame, L.A., Otieno, M., Park, M., Potts, S.G., Rundlof, M., Saez, A., Steffan-Dewenter, I., Taki, H., Viana, B.F., Westphal, C., Wilson, J.K., Greenleaf, S.S., Kremen, C., 2013. A global quantitative synthesis of local and landscape effects on wild bee pollinators in agroecosystems. Ecol. Lett. 16, 584-599.

Klatt, B.K., Holzschuh, A., Westphal, C., Clough, Y., Smit, I., Pawelzik, E., Tscharntke, T., 2014. Bee pollination improves crop quality, shelf life and commercial value. Proc. R. Soc. B 281, 20132440.

Kleijn, D., Winfree, R., Bartomeus, I., Carvalheiro, L.G., Henry, M., Isaacs, R., Klein, A.M., Kremen, C., M'Gonigle, L.K., Rader, R., Ricketts, T.H., Williams, N.M., Lee Adamson, N., Ascher, J.S., Báldi, A., Batáry, P., Benjamin, F., Biesmeijer, J.C., Blitzer, E.J., Bommarco, R., Brand, M.R., Bretagnolle, V., Button, L., Cariveau, D.P., Chifflet, R., Colville, J.F., Danforth, B.N., Elle, E., Garratt, M.P.D., Herzog, F., Holzschuh, A., Howlett, B.G., Jauker, F., Jha, S., Knop, E., Krewenka, K.M., Le Féon, V., Mandelik, Y., May, E.A., Park, M.G., Pisanty, G., Reemer, M., Riedinger, V., Rollin, O., Rundlöf, M., Sardiñas, H.S., Scheper, J., Sciligo, A.R., Smith, H.G., SteffanDewenter, I., Thorp, R., Tscharntke, T., Verhulst, J., Viana, B.F., Vaissière, B.E., Veldtman, R., Ward, K.L., Westphal, C., Potts, S.G., 2015. Delivery of crop pollination services is an insufficient argument for wild pollinator conservation. Nat. Commun. 6, 7414.

Kleijn, D., Bommarco, R., Fijen, T.P., Garibaldi, L.A., Potts, S.G., van der Putten, W.H. 2019. Ecological intensification: bridging the gap between science and practice. Trends Ecol. Evol. 34, 154-166.

Klein, A.M., Vaissiere, B.E., Cane, J.H., Steffan-Dewenter, I., Cunningham, S.A., Kremen, C., Tscharntke, T., 2007. Importance of pollinators in changing landscapes for world crops. Proc. R. Soc. B 274, 303-313.

Kleinman, D.L., Suryanarayanan, S., 2019. Pollinating collaboration: diverse stakeholders' efforts to build experiments in the wake of the honey bee crisis. Sci. Technol. Hum. Values, 0162243919865962.

Lautenbach, S., Seppelt, R., Liebscher, J., Dormann, C.F., 2012. Spatial and temporal trends of global pollination benefit. PLoS One 7, e35954.

Liu, P.F., Li, H.Y., 2014. Evaluation of honeybee pollination value based on alternative value method - taking apple and pear pollination in Shanxi Province as an example. APIC China 65, 49-52 (in Chinese).

Liu, Y.Z., Miao, R.H., Chen, A.Q., Miao, Y., Liu, Y.J., Wu, X.W., 2017. Effects of nitrogen addition and mowing on reproductive phenology of three early-flowering forb species in a Tibetan alpine meadow. Ecol. Eng. 99, 119-125.

Marini, L., Tamburini, G., Petrucco-Toffolo, E., Lindström, S.A.M., Zanetti, F., Mosca, G., Bommarco, R., 2015. Crop management modifies the benefits of insect pollination in oilseed rape. Agric. Ecosyst. Environ. 207, 61-66.

Martins, K.T., Gonzalez, A., Lechowicz, M.J., 2015. Pollination services are mediated by bee functional diversity and landscape context. Agric. Ecosyst. Environ. 200, 12-20.

Nielsen, A., Steffan-Dewenter, I., Westphal, C., Messinger, O., Potts, S.G., Roberts, S.P., Settele, J., Szentgyörgyi, H., Vaissière, B.E., Vaitis, M., Woyciechowski, M., Bazos, I., Biesmeijer, J.C., Bommarco, R., Kunin, W.E., Tscheulin, T., Lamborn, E., Petanidou, T., 2011. Assessing bee species richness in two Mediterranean communities: importance of habitat type and sampling techniques. Ecol. Res. 26, 969-983.

Pardo, A., Borges, P.A.V., 2020. Worldwide importance of insect pollination in apple orchards: a review. Agric. Ecosyst. Environ. 293, 106839.

Park, M.G., Blitzer, E.J., Gibbs, J., Losey, J.E., Danforth, B.N., 2015. Negative effects of pesticides on wild bee communities can be buffered by landscape context. Proc. R. Soc. B 282, 20150299.

Potts, S.G., Biesmeijer, J.C., Kremen, C., Neumann, P., Schweiger, O., Kunin, W.E., 2010. Global pollinator declines: trends, impacts and drivers. Trends Ecol. Evol. 25, 345-353.
R Core Team, 2018. R: A Language and Environment for Statistical Computing. R Foundation for Statistical Computing, Vienna, Austria.

Ramírez, F., Davenport, T.L., 2013. Apple pollination: a review. Sci. Hortic. 162, 188-203.

Ramos, D.D.L., Bustamante, M.M., e Silva, F.D.D.S., Carvalheiro, L.G., 2018. Crop fertilization affects pollination service provision - common bean as a case study. PLoS One 13, e0204460.

Ripley, B., Venables, B., Bates, D.M., Hornik, K., Gebhardt, A., Firth, D., Ripley, M.B., 2018. Mass: support functions and datasets for Venables and Ripley's MASS. R package version 7, 3-50.

Rollin, O., Bretagnolle, V., Decourtye, A., Aptel, J., Michel, N., Vaissière, B.E., Henry, M., 2013. Differences of floral resource use between honey bees and wild bees in an intensive farming system. Agric. Ecosyst. Environ. 179, 78-86.

Sapir, G., Baras, Z., Azmon, G., Goldway, M., Shafir, S., Allouche, A., Stern, E., Stern, R. A., 2017. Synergistic effects between bumblebees and honey bees in apple orchards increase cross pollination, seed number and fruit size. Sci. Hortic. 219, 107-117.

Schweiger, O., Biesmeijer, J.C., Bommarco, R., Hickler, T., Hulme, P., Klotz, S., Kühn, I., Moora, M., Nielsen, A., Ohlemuller, R., Petanidou, T., Potts, S.G., Pysek, P., Stout, J. C., Sykes, M., Tscheulin, T., Vilà, M., Wather, G.-R., Westphal, C., 2010. Multiple stressors on biotic interactions: how climate change and alien species interact to affect pollination. Biol. Rev. 85, 777-795.

Steffan-Dewenter, I., Münzenberg, U., Bürger, C., Thies, C., Tscharntke, T., 2002. Scaledependent effects of landscape context on three pollinator guilds. Ecology 83, 1421-1432.

Steward, P.R., Shackelford, G., Carvalheiro, L.G., Benton, T.G., Garibaldi, L.A., Sait, S.M., 2014. Pollination and biological control research: are we neglecting two billion smallholders. Agric. Food Secur. 3, 5.

Tamburini, G., Lami, F., Marini, L., 2017. Pollination benefits are maximized at intermediate nutrient levels. Proc. R. Soc. B. 284, 20170729.

Tscharntke, T., Tylianaskis, J.M., Rand, T.A., Didham, R.K., Fahrig, L., Batáry, P., Bengtsson, J., Clough, Y., Crist, T.O., Dormann, C.F., Ewers, R.M., Holt, R.D., Holzschuh, A., Klein, A.M., Kremen, C., Landis, D.A., Laurance, W., Lindenmayer, D., Scherber, C., Sodhi, N., Steffan-Dewenter, I., Thies, C., van der Putten, W.H., Westphal, C., 2012. Landscape moderation of biodiversity patterns and processes eight hypotheses. Biol. Rev. 87, 661-685.

Tylianakis, J.M., Didham, R.K., Bascompte, J., Wardle, D.A., 2008. Global change and species interactions in terrestrial ecosystems. Ecol. Lett. 11, 1351-1363.

Vanbergen, A.J., the Insect Pollinators Initiative, 2013. Threats to an ecosystem service: pressures on pollinators. Front. Ecol. Environ. 11, 251-259.

Veddeler, D., Klein, A.M., Tscharntke, T., 2006. Contrasting responses of bee communities to coffee flowering at different spatial scales. Oikos 112, 594-601.

Vicens, N., Bosch, J., 2000. Weather-dependent pollinator activity in an apple orchard, with special reference to Osmia cornuta and Apis mellifera (Hymenoptera: Megachilidae and Apidae). Environ. Entomol. 29, 413-420.

Visser, T., Verhaegh, J.J., 1980. Pollen and pollination experiments. I. The contribution of stray pollen to the seed set of depetalled, hand-pollinated flowers of apple. Euphytica 29, 379-383.

Volz, R.K., Harker, F.R., Lang, S., 2003. Firmness decline in Gala' apple during fruit development. J. Am. Soc. Hortic. Sci. 128, 797-802.

Wang, L.N., Zhuo, Y., Ouyang, F., Xiao, Y.L., Qu, C.H., Ye, B.H., Men, X.Y., 2018. Releasing Osmia excavata Alfken pheromones increases pollination activity and improves fruit set and quality. Chin. J. Appl. Entomol. 55, 994-1000 (in Chinese).

Westphal, C., Bommarco, R., Carre, G., Lamborn, E., Morison, N., Petanidou, T., Potts, S. G., Roberts, S.P.M., Szentgyoergyi, H., Tscheulin, T., Vaissiere, B.E.,

Woyciechowski, M., Biesmeijer, J.C., Kunin, W.E., Settele, J., Steffan-Dewenter, I., 2008. Measuring bee diversity in different European habitats and biogeographical regions. Ecol. Monogr. 78, 653-671.

Westphal, C., Vidal, S., Horgan, F.G., Gurr, G.M., Escalada, M., Van Chien, H., Tscharntke, T., Heong, K.L., Settele, J., 2015. Promoting multiple ecosystem services with flower strips and participatory approaches in rice production landscapes. Basic Appl. Ecol. 16, 681-689.

Wietzke, A., Westphal, C., Gras, P., Kraft, M., Pfohl, K., Karlovsky, P., Pawelzik, E., Tscharntke, T., Smit, I., 2018. Insect pollination as a key factor for strawberry physiology and marketable fruit quality. Agric. Ecosyst. Environ. 258, 197-204.

Winfree, R., Fox, J.W., Williams, N.M., Reilly, J.R., Cariveau, D.P., 2015. Abundance of common species, not species richness, drives delivery of a real-world ecosystem service. Ecol. Lett. 18, 626-635.

Wu, Y.R., 1965. Economic Insect Fauna of China. Fasc. 9. Hymenoptera: Apoidea. Science Press, Beijing, China (in Chinese).

Wu, Y.R., 2000. Fauna Sinica. Insect Vol. 20. Hymenoptera: Melittidae, Apidae. Science Press, Beijing, China (in Chinese).

Wu, P.L., Axmacher, J.C., Li, X.D., Song, X., Yu, Z.R., Xu, H.L., Tscharntke, T., Westphal, C., Liu, Y.H., 2019. Contrasting effects of natural shrubland and plantation forests on bee assemblages at neighboring apple orchards in Beijing, China. Biol. Conserv. 237, 456-462.

Xia, J., Wan, S., 2013. Independent effects of warming and nitrogen addition on plant phenology in the Inner Mongolian steppe. Ann. Bot. 111, 1207-1217.

Xia, S.J., Wang, C., Zhang, D., Yang, X.S., He, J.Z., 2018. Analysis of apple yield difference and limiting factors in Luochuan County. J. Shanxi Agric. Sci. 46, 2077-2081 (in Chinese).

Yang, X.S., Zhao, L.B., Zhang, D., Wang, C., Qu, J.T., 2017. Status and countermeasures of fertilization in apple orchards in Luochuan County. Shaanxi J. Agric. Sci. 63, 61-63 (in Chinese).

Zhang, X., Davidson, E.A., Mauzerall, D.L., Searchinger, T.D., Dumas, P., Shen, Y., 2015. Managing nitrogen for sustainable development. Nature 528, 51-59. 
Zhao, Z.P., Tong, Y.A., Liu, F., Wang, X.Y., Zeng, Y.J., 2012. Assessment of current conditions of household fertilization of apples in Weibei Plateau. Chin J. Eco-Agric. 20, 1003-1009 (in Chinese).

Zhao, G., Mu, X., Wen, Z., Wang, F., Gao, P., 2013. Soil erosion, conservation, and ecoenvironment changes in the Loess Plateau of China. Land Degrad. Dev. 24, 499-510.

Zhao, Z.H., Yang, P.Y., Li, P., Zhou, Y., Ren, B.Y., 2015. Preliminary report on integration application and demonstration effect of bee pollination and green prevention and control stimulation technology. China Plant Prot. 35, 43-45 (in Chinese).

Zou, Y., Sang, W.G., Wang, S.Z., Warren-Thomas, E., Liu, Y.H., Yu, Z.R., Wang, C.L., Axmacher, J.C., 2015. Diversity patterns of ground beetles and understory vegetation in mature, secondary, and plantation forest regions of temperate Northern China. Ecol. Evol. 5, 531-542.

Zou, Y., Bianchi, F.J.J.A., Jauker, F., Xiao, H.J., Chen, J.H., Cresswell, J., Luo, S.D., Huang, J.K., Deng, X.Z., Hou, L.L., van der Werf, W., 2017. Landscape effects on pollinator communities and pollination services in small-holder agroecosystems. Agric. Ecosyst. Environ. 246, 109-116.

Zurbuchen, A., Landert, L., Klaiber, J., Müller, A., Hein, S., Dorn, S., 2010. Maximum foraging ranges in solitary bees: only few individuals have the capability to cover long foraging distances. Biol. Conserv. 143, 669-676.

Zuur, A., Ieno, E.N., Walker, N., Saveliev, A.A., Smith, G.M., 2009. Mixed Effects Models and Extensions in Ecology With R. Springer, New York. 